\title{
Community structure and diversity of a tropical dry deciduous forest of Hastinapur region, India
}

\author{
Poonam Khurana \\ Department of Botany, Meerut College, Meerut (U.P.), INDIA \\ E-mail: miss_khurana80@yahoo.co.in
}

\begin{abstract}
The present study deals with quantitative analysis of vegetation of forest area in Hastinapur, India. A total 3 sites were selected for the study. The values of density and total basal area for different species ranged from 0.5 Ind $100 \mathrm{~m}^{-2}$ to 2.2 and $16.50 \mathrm{~cm}^{2}$ tree ${ }^{-1}$ to $1055.0 \mathrm{~cm}^{2}$ tree $^{-1}$. Most of the species on different sites were randomly and regularly distributed, none of the species were found with contagious distribution. The values of $\mathrm{Cd}$ and $\mathrm{H}^{\prime}$ were ranged from 0.003 to 0.035 and 0.000 to 0.014 .
\end{abstract}

Keywords: Community structure, Distribution pattern, Concentration of dominance, Species diversity.

\section{INTRODUCTION}

Hastinapur region of North West Uttar Pradesh is part of north upper Gangetic plain. The whole region is tract of various classes of fertile soil. The vegetation in the Gangetic plain is generally of tropical dry deciduous type, which is degraded to open scrub jungles because of population pressure, extensive agricultural practices and extensive felling of trees due to human interference. Besides this change in environmental conditions, the vegetation reflects changes in its structure, density and composition (Gaur, 1982). The most important structural property of a community is a definite quantitative relationship between abundant and rare species. The study of floristic composition and phytosociological attributes are useful for comparing one community to the other from season to season and year to year (Singh, 1976). Species content and their ecological amplitude determine structure and nature of plant community. This includes the investigation of species composition and sociological interaction of species in communities (MullerDombois and Ellenberg, 1974). The chronic form of disturbances occuring in forest adversaly influence the succession, growth and surviva of seedlings and sapling. Regenration in many indian forest is inadequate to replace the adults (Sukumar et al.,1992). conservation of thse forest will depand on an understanding of forest ecosystem dynamics (Sussman and Rokotozfy, 1994).

Soil is a medium of all plant productivity. The vegetation influences the physical and chemical properties of soil to a great extent. It improves the soil structure, infiltration rate and water holding capacity. Das et al.(1980) showed that the nature and content of organic debris returns to the forest floor varying with vegetation affecting the physic-chemical properties of soil from the direct impact of raindrops thereby controlling erosion and increase the moisture status of the soil.Several studies have been undertaken on community structure and organization in natural forest in different climatic zones of india by different workers Chandra (1996), Kumar and Kumar (1997), Varghese and Menon (1998), Shadangietal.(2000), Pande (2001),Sagar et al. (2003), Kumar et.al.(2005), Sanjeev et.al.(2006). Anthropogenic factors regularly affects the diversity and structurer of forest so it became necessary to study forest as per their quantitative characters so that its future pattern can be predicted.

\section{MATERIALS AND METHODS}

Study area: The present study was carried out in natural forest of Hastinapur $36.4 \mathrm{~km}$ north east to Meerut district. It lies at $29^{\circ} 1^{\prime} \mathrm{N}$ latitude and $77^{\circ} 9^{\prime} \mathrm{E}$ longitudes and has an elevation of $215 \mathrm{mt}$ above the sea level. The area receives an average annual rain fall of $760 \mathrm{~mm}$ to $890 \mathrm{~mm}$ mainly concentrated during the period of July- September. In summers the maximum temperature rises up to $42^{\circ} \mathrm{C}$ and the minimum temperature falls down to $2^{\circ} \mathrm{C}$ in the cold frosty nights of December and January. The vegetation is at its zenith during the rainy season because of high humidity and moderate temperature.

Sampling method and collection of data: The field study period extended over the months of July-November 2004. Three sites were selected for the present study (Hillock, Block-1 and Block-2) of these hillock was highly disturbed while Block-1 was moderately disturbed and Block-2 was least disturbed. A walk through survey was carried out to get a picture of the entire vegetation falling under the study area. The size and number of the quadrate were determined by were determined by species area curve method. The number of quadrats against the number of species (Mishra, 1968). Total 30 quadrate of $10 \times 10 \mathrm{~m}$ for 
trees and 60 quadrates of $2 \times 2 \mathrm{~m}$ (within 30 quadrats of $10 \times 10 \mathrm{~m}$ ) were randomly placed for seedlings, saplings shrubs and herbs. In every quadrat data on name of species cbh (circumference at breast height) were recorded for all the species.

Soil analysis : The soil characteristics were evaluated by collecting three soil samples at different depth i.e horizon A $(0-10 \mathrm{~cm})$ horizon B $(10-20 \mathrm{~cm})$ horizon C $(20-30$ $\mathrm{cm})$ in the studies forest sites, were analyzed for the physic chemical properties of the soil. Soil reaction was assessed by a control dynamic digital $\mathrm{pH}$ meter. The organic carbon percentage was determined by Walkley and Black's rapid titration method (Walkley and Black, 1934). Available phosphorus was determined by phosphomolybendenum blue calorimetric method (Jackson, 1958) and exchangeable potassium was determined by flame photometer after leaching soil with I.P ammonium acetate solution (Jackson, 1958)

Vegetation analysis: The phytosociology of woody vegetation was carried out by laying down quadrates of $10 \times 10 \mathrm{~m}$ size randomly which was determined by species area curve method (Misra, 1968) and the running mean method (Kershaw, 1973). The trees more than $31.5 \mathrm{~cm}$ Cbh (circumference at brest height) i.e $1.37 \mathrm{mt}$ above the ground, were individually measured either as sapling or as shrub and the individual less than $10.5 \mathrm{~cm}$ cbh were considered as seedlings (Knight, 1975). The vegetation was quantitatively analyzed for density, frequency and abundance following Curtis and Mc Intosh (1950). The relative values were determined as per Curtis (1959). The diversity index was calculated following Shannon and weiner (1963) method as $\mathbf{H}=\mathrm{S}(\mathbf{N i} / \mathbf{N}) \log _{2}(\mathbf{N i} / \mathbf{N})$. The concentration of dominance $(\mathrm{Cd})$ was determined by Simpson's index as $\mathrm{Cd}=\mathrm{S}(\mathrm{Ni} / \mathrm{N})^{2}$ (Simpsons, 1949). Distribution pattern was calculated as per Curtis and Cottam (1956).

\section{RESULTS AND DISCUSSION}

Soil analysis: The soil of the forest was coarse in texture i.e sand predominating the area. The water holding or field capacity percentage has been found to be higher for Hillock site; it varies from $72.39 \%$ (horizon A of Block2) to $91.58 \%$ (horizon $\mathrm{B}$ of hillock). The $\mathrm{pH}$ of the soil ranged from 7.26 to 8.52 which indicate that the soil was slightly alkaline in nature. The availability of nutrient content was not enough due to low decomposition rate of organic matter and secondly removal of litter by the villagers for their daily local needs. The range of organic carbon was ranging from 0.37 (horizon c of Block-2) to 1.18 (Horizon A of block-1). The nitrogen content in different layers of soil was found ranging from 165.92 (horizon C of block-2) to 287.26 (Horizon A of Block-1). The availability of Phosphorus was raging from 33.60 (Horizon B of Block-2) to 274.40 (Horizon A of Hillock) available $\mathrm{K}$ was ranging from 50.40 (Horizon B of Block2) to 544.88 (Horizon B of Hillock) (Table 1).

Phytosociological analysis: The dominant species on Hillock, Block-1 and Block-2 (Table 2) was Acacia nilotica. Acacia nilotica and Acacia catechu were showing highest IVI values of 77.63, 48.91 and25.64. Composition of tree species showed little variation, which might be due to similar climatic conditions. There were lowest number of trees (83) at Hillock, as compared to Block-1 (95) and Block-2 (99). As Hillock forest site is

Table 1. Physico-chemical properties of soil in different study sites

\begin{tabular}{|c|c|c|c|c|c|c|c|c|c|c|}
\hline \multirow[t]{2}{*}{ Site/Horizon } & \multicolumn{3}{|c|}{ Texture } & \multirow{2}{*}{$\begin{array}{c}\text { Water } \\
\text { holding } \\
\text { Capacity } \\
(\%)\end{array}$} & \multirow{2}{*}{$\begin{array}{c}\text { Bulk } \\
\text { density } \\
\left(\mathrm{mg} / \mathrm{cm}^{3}\right)\end{array}$} & \multirow{2}{*}{$\begin{array}{l}\text { Organic } \\
\text { Carbon } \\
\text { (Mean } \\
\pm \text { S.D) }\end{array}$} & \multirow{2}{*}{$\begin{array}{c}\text { Soil } \\
\text { pH }\end{array}$} & \multirow{2}{*}{$\begin{array}{c}\text { Available } \\
\text { Nitrogen } \\
\text { (kg/ha.) } \\
\text { (Mean } \pm \text { S.D) }\end{array}$} & \multirow{2}{*}{$\begin{array}{c}\text { Available } \\
\text { Phosphorous } \\
\text { (kg/ha.) } \\
\text { (Mean } \pm \text { S.D) }\end{array}$} & \multirow{2}{*}{$\begin{array}{c}\text { Available } \\
\text { Potassium } \\
\text { (kg/ha.) } \\
\text { (Mean } \pm \text { S.D) }\end{array}$} \\
\hline & $\begin{array}{l}\text { Sand } \\
(\%)\end{array}$ & $\begin{array}{l}\text { Silt } \\
(\%)\end{array}$ & $\begin{array}{l}\text { Clay } \\
(\%)\end{array}$ & & & & & & & \\
\hline \multicolumn{11}{|l|}{ Hillock } \\
\hline Horizon A & 84 & 8 & 8 & 91.51 & 1.47 & $0.50 \pm 0.014$ & 7.65 & $185.40 \pm 74.20$ & $274.40 \pm 33.00$ & $453.82 \pm 7.60$ \\
\hline Horizon B & 82 & 8 & 10 & 91.58 & 1.44 & $0.47 \pm 0.014$ & 8.08 & $180.90 \pm 43.41$ & $272.16 \pm 18.21$ & $544.88 \pm 3.67$ \\
\hline Horizon C & 78 & 6 & 16 & 88.89 & 1.44 & $0.47 \pm 0.014$ & 8.23 & $180.90 \pm 59.63$ & $217.28 \pm 3.324$ & $520.8 \pm 2.02$ \\
\hline \multicolumn{11}{|l|}{ B lock-1 } \\
\hline Horizon A & 88 & 2 & 10 & 78.82 & 1.69 & $1.18 \pm 0.084$ & 7.45 & $287.26 \pm 44.63$ & $40.32 \pm 0.340$ & $207.76 \pm 4.06$ \\
\hline Horizon B & 88 & 2 & 10 & 77.28 & 1.52 & $0.62 \pm 0.058$ & 7.26 & $202.75 \pm 3.870$ & $40.32 \pm 0.436$ & $186.76 \pm 6.20$ \\
\hline Horizon C & 88 & 3 & 9 & 72.93 & 1.66 & $0.94 \pm 0.077$ & 7.69 & $250.37 \pm 0.514$ & $44.80 \pm 4.022$ & $155.68 \pm 10.05$ \\
\hline \multicolumn{11}{|l|}{ Block-2 } \\
\hline Horizon A & 84 & 8 & 8 & 72.39 & 1.70 & $0.40 \pm 0.021$ & 8.24 & $170.42 \pm 5.196$ & $38.08 \pm 8.72$ & $77.84 \pm 2.04$ \\
\hline Horizon B & 90 & 0 & 10 & 76.68 & 1.66 & $0.45 \pm 0.027$ & 8.38 & $177.91 \pm 39.23$ & $33.60 \pm 1.67$ & $50.40 \pm 0.75$ \\
\hline Horizon C & 90 & 2 & 8 & 74.28 & 1.61 & $0.37 \pm 0.027$ & 8.52 & $165.92 \pm 2.25$ & $40.32 \pm 0.45$ & $52.64 \pm 2.42$ \\
\hline
\end{tabular}


Table-2. Density, Total basal cover and IVI of tree species in different study sites.

Hillock

\begin{tabular}{|c|c|c|c|c|}
\hline S.N & species & Density $\left(\operatorname{Ind} 100 \mathrm{~m}^{-2}\right)$ & Total basal cover & IV I \\
\hline 1 & Acacia nilotica & 2.2 & 1055.0 & 77.63 \\
\hline 2 & Acacia farnesiana & 1.6 & 718.81 & 59.07 \\
\hline 3 & Acacia catechu & 1.5 & 661.35 & 54.07 \\
\hline 4 & Propsopis juliflora & 1.9 & 633.04 & 58.11 \\
\hline 5 & Dalbergia sissoo & 0.5 & 387.41 & 27.81 \\
\hline 6 & Tectona grandis & 0.6 & 257.88 & 23.26 \\
\hline \multicolumn{5}{|l|}{ Block 1} \\
\hline S.N & species & Density (Ind100m') & $\begin{array}{c}\text { Total basal cover } \\
\left(\mathrm{cm}^{2} \text { tree }^{-1}\right)\end{array}$ & IVI \\
\hline 1 & Acacia nilotica & 2.0 & 540.36 & 48.91 \\
\hline 2 & Eucalyptus globules & 1.4 & 511.50 & 38.53 \\
\hline 3 & Bauhinia racemosa & 0.9 & 526.59 & 31.92 \\
\hline 4 & $\begin{array}{l}\text { Heterophragma } \\
\text { adenophyllum }\end{array}$ & 0.9 & 478.98 & 30.80 \\
\hline 5 & Butea monosperma & 0.8 & 460.84 & 27.62 \\
\hline 6 & Cassia fistula & 0.6 & 364.23 & 25.40 \\
\hline 7 & Tectona grandis & 0.8 & 315.48 & 24.08 \\
\hline 8 & Pongamia Pinnata & 0.7 & 364.08 & 24.34 \\
\hline 9 & Bauhinia racemosa & 0.6 & 396.9 & 24.04 \\
\hline 10 & Albizzia lebbek & 0.6 & 395.87 & 24.02 \\
\hline \multicolumn{5}{|l|}{ Block 2} \\
\hline S.N & species & Density (Ind100m $\left.{ }^{-2}\right)$ & $\begin{array}{c}\text { Total basal cover } \\
\left(\mathrm{cm}^{2} \text { tree }^{-1}\right)\end{array}$ & IVI \\
\hline 1 & Acacia catechu & 0.8 & 696.6 & 25.64 \\
\hline 2 & Tectona grandis & 0.7 & 431.64 & 22.74 \\
\hline 3 & Cassia fistula & 0.8 & 510.77 & 23.83 \\
\hline 4 & Ailanthus excels & 0.9 & 416.74 & 23.44 \\
\hline 5 & Butea monosperma & 0.8 & 483.38 & 23.39 \\
\hline 6 & Phoenix sylvestris & 0.8 & 331.6 & 20.89 \\
\hline 7 & Bauhinia purpurea & 0.8 & 346.19 & 19.87 \\
\hline 8 & Dalbergia sissoo & 0.7 & 366.09 & 19.21 \\
\hline 9 & Acacia nilotica & 0.5 & 418.51 & 18.06 \\
\hline 10 & Pongamia pinnata & 0.5 & 323.85 & 16.50 \\
\hline 11 & Bauhinia variegate & 0.6 & 336.06 & 16.36 \\
\hline 12 & Bauhinia racemosa & 0.5 & 340.06 & 15.53 \\
\hline 13 & Pithecolobium dulce & 0.4 & 348.70 & 14.40 \\
\hline 14 & Albizia lebbek & 0.4 & 270.60 & 13.38 \\
\hline 15 & Eucalyptus globules & 0.4 & 236.25 & 12.82 \\
\hline 16. & Diospyros cordifolia & 0.3 & 202.31 & 10.03 \\
\hline
\end{tabular}

frequently subjected to anthropogenic interferences which wiped out a number of plant species, also this interference in forest causes remarkable changes in vegetation diversity and species composition Verma etal.(1997). Total basal area varied from $257.88 \mathrm{~cm} 2100 \mathrm{~m}-2$ (Tectona grandis) to $1055.0 \mathrm{~cm} 2100 \mathrm{~m}-2$ (Acacia nilotica) for Hillock.

There was great variation in range of basal covers in the sites. Trees of Hillock showed higher girth classes which indicates this site is dominated by trees of mature age and values of basal cover fall in range reported by Singh et al. (1981) for silent valley. According to Saxena et al. (1978) the trees with higher basal area indicate the best performance of the species and lower basal area either demarcated the chance occurrence of the species or biotic disturbances of the past. Low density of trees (Table-3) indicates that tree canopy is getting open in Hillock due to disturbances.

Distribution pattern: The abundance to frequency ratio indicates that among all the study sites most of the species showed regular and random distribution pattern. The pattern of distribution depends both on physicchemical properties of environment as well as on the biological peculiarities of the organism themselves. According to Odum (1971) in natural conditions contagious distribution is most common, preponderance of regular as well as random distribution reflects the magnitude of biotic interference such as grazing and looping in the forest sites. 
Table 3. Values of total tree basal area, total tree density in different study sites of Hastinapur.

\begin{tabular}{ccc}
\hline Site & $\begin{array}{c}\text { Total tree basal area } \\
\text { cm }^{\mathbf{2}} \mathbf{1 0 0}^{-2}\end{array}$ & $\begin{array}{c}\text { Total tree } \\
\text { density } \\
\text { (tree100m-2) }\end{array}$ \\
\hline Hillock & 3713.49 & 8.3 \\
Block-1 & 4354.83 & 9.5 \\
Block-2 & 6095.35 & 9.9 \\
\hline
\end{tabular}

Table 4. Distribution pattern, concentration of dominance (CD) and species diversity ( $\mathrm{H}^{\prime}$ ) of different forest sites of Hastinapur region.

\begin{tabular}{cccccc}
\hline Site & Regular & Random & Contagious & CD & H \\
\hline Hillock & 50.00 & 50.00 & - & 0.035 & 0.014 \\
Block-1 & 50.00 & 50.00 & - & 0.010 & 0.002 \\
Block-2 & 56.25 & 43.75 & - & 0.003 & 0.000 \\
\hline
\end{tabular}

Diversity (H') and concentration of dominance (CD): The values of diversity and $\mathrm{CD}$ in different studied sites have been presented in Table 4 . The diversity values were ranging from 0.00 (Block-2) to 0.014 (Hillock) and CD values were reported from 0.003 (Block-2) to 0.035 (Hillock). These calculated values were more than $50 \%$ lower than those for tropical forest reported by Knight (1975). The possible reason for low diversity index may be aridity of the area and also possible habitat destruction which leads to less number of species and their individuals. However higher value of diversity index for Hillock can be attributed to a greater degree of repeated disturbances, which generated more hetergenous environment, giving opportunity for colonization of the varied species (Shah et al., 1998). Lower values of CD indicates that in this forest dominance is shared by more than one species, but these values of $\mathrm{Cd}$ are high in accordance with low species diversity ( $\left.\mathrm{H}^{\prime}\right)$, because species diversity ( $\left.H^{\prime}\right)$ behave inversely to the index of dominance (Odum,1971).

\section{REFERENCES}

Chandra, R. (1996). Quantitative pattern of reparian woody vegetation along elevational gradient in Kumaun Himalaya. J. Ecobiology, 8(4): 243-250.

Curtis, J.T. and Cottam,G. (1956). Plant ecology workbook. Laboratory field reference manual Burgess publishing Co. Minnesota. $193 \mathrm{p}$

Curtis, J.T. (1959). The vegetation of Wisconsin. An ordination of plant communities. Univ. Wisconsin press, Madison, Wisconsin. 657p.

Curtis, J.T. and Mac Intosh, R.P. (1950). The interaction of certain analytic and synthetic phytosociological characters. Ecology, 31: 434-455.

Das, S.N., Maili, T.C. and Banerjee, S.K. (1980). Genesis of red and lateritic forest soil of west Bengal on centenary basis, Part-1, Morphological studies, Indian Forester, 106(10):704-714

Gaur, R.D.(1982). Dynamics of vegetation of Garwhal Himalaya. In(p12).(Paliwal G.S., ed.)

Jackson, M.L.(1958). Soil chemical analysis. Pentice Hall, Inc., Englewood cliffs, NJ, U.S.A. P.498.
Kershaw, R.K.(1973). Quantitative and dynamic plant ecology. Edward Arnold Ltd. London pp.3.8.

Knight, D.H. (1975). A phytosociological analysis of species rich tropical forest on Barro Colorado Island Panama. Ecological Monograph,45: 259-284.

Kumar, Munesh, Rajwar Govind S., Sharma, C.M. and Dhaulkhandi, Manoj (2005). Distribution pattern and diversity in herbaceous plant community in a Temperate forest of Garwhal Himalaya. Annl. Fores., 13(1): 167-174.

Kumar, S.S and Kumar, B.M. (1997). Floristic biomass production and edaphic attributes in Mangrove forest of Puduvyppu Kerala. Indian J. of Forestry, 20(2): 136-143.

Mishra, R. (1968). Ecology work book. Oxford and IBH publishing company Calcutta.

Muller- Dombois, D. and Ellenberg, E. (1974). Aims and method of vegetation ecology. JohnWiley \& sons New York.

Odum, E.P. (1971). Fundamentals of Ecology. Oxford and IBH publishing Co. New Delhi. 244 p.

Pande, P.K. (2001). Quantitative vegetation analysis as per aspect and altitude and regeneration behaviour of tree species in Garwhal Himalayan forest. Ann. Fores., 9(1): 39-52.

Sagar, R., Raghubanshi, A.S. and Singh, J.S. (2003). Tree species composition dispersion and diversity along disturbance gradient in dry tropical region of India. Forest ecology and Management, 186(1/3): 61-71.

Sanjeev, Gera Mohit and Sankhayayan Prem Lal (2006). Phytosociological analysis of Arnigad Microwatershed in Mussorie Hiils of Gaewhal Himalaya. Ind. Forester., (Jan) 19-29.

Saxena, A.K., Pandey uma, and Singh, J.S. (1978). On the ecology of Oak forest in Nainital hills Kumaun Himalaya. In: (Singh, J.S. and Gopal, B. Eds.) Glimpses of Ecology. International scientific publication, Jaipur. 167-180.

Shadangi, D.K, Banerjee, S.K; Shukla, P.K and Soni Manoj (2000). Compartive studies on plant diversity in protected forest area under joint forest management and unprotected forest in Orissa. I.J of Trop. Biodiversity. 7-8 (1-4): 15-22

Shannon, C.E and Weiner, W. (1963). The mathematical theory of communication, Univ. Illinois Press Uganda.

Simpson, E.N. (1949). Measurment of diversity. Nature, 163: 688. Singh, R.(1976). Structure and net community production of the herbaceous vegetation in the sand dune region around Pilani, Rajasthan. 460pp Ph.D thesis. BITS Pilanai, Rajasthan vegetational wealth of the Himalaya.

Singh, J.S., Singh, S.P, Saxena, A.K. and Rawat, Y.S.(1981). The silent valley forest ecosystem and possible impact of proposed hydroelectric project on the silent valley study. Ecology research circle. Kumaun University, Nainital.70p.

Sussman, R.W. and Rokotozafy, A. (1994). Plant diversity and structural analysis of a tropical dry forest in southern Madagascar. Biotropica., 26: 241-254.

Varghese, A.O and Menon, A.R.R. (1998). Vegetation characteristics of southern semidry moist deciduous forest of Agasthyamalai region of Kerala. Indian Journal of Forestry, 21(4): 337-344.

Verma, R.K;Totey, N.G. and Gupta, B.N. (1997). Analysis of forest vegetation in the permanat preservation plot of Tamna in Orissa. Indian Forester, 123 (11): 1007-1016.

Walkely, A.E. and Black, J.A. (1934). An examination of the Degtiga Vett. Method for determining soil organic matter and proposed modification of the chromic acid titration method. Soil Sci., 37:29. 